\title{
Biochemical and microbiological quality of fermented silage prepared from dressing waste of Indian major carps using different concentrations of jaggery
}

\author{
S. TANUJA, ${ }^{*}$ ANIL KUMAR, A. SARKAR AND SUJIT K. NAYAK \\ ICAR-Central Institute for Women in Agriculture, Baramunda Post, Bhubaneswar - 751 003, Odisha, India \\ e-mail: tanujasomarajan@gmail.com
}

\begin{abstract}
Present study investigated the shelf life of fermented silage prepared from dressing waste (gut and gills) of Indian major carps and the effect of different concentrations of jaggery as carbohydrate source, on the biochemical and microbiological changes in the silage. Fermented silage was prepared using jaggery at $10 \% \mathrm{w} / \mathrm{w}(\mathrm{F} 1)$ and $20 \% \mathrm{w} / \mathrm{w}(\mathrm{F} 2)$ concentrations. F2 had a lower crude fat and ash content. The lowest $\mathrm{pH}$ attained was 4.11 and 4.02 in F1 and F2 respectively by the end of 15 days. Significantly higher $(\mathrm{p}<0.05)$ concentration of total volatile base nitrogen (TVB-N) was observed in F2 from the $30^{\text {th }}$ day of storage. The rate of auto-oxidation was also significantly higher in F2 throughout the storage period of 60 days. Total plate count (TPC) of bacteria in F1 and F2 reduced significantly till the $15^{\text {th }}$ day of storage. At the end of 60 days of storage, $\mathrm{pH}$ reached 5.55 and $5.67 \mathrm{in} \mathrm{F1} \mathrm{and} \mathrm{F2} \mathrm{respectively,} \mathrm{thereafter} \mathrm{the} \mathrm{silage} \mathrm{was} \mathrm{considered} \mathrm{spoiled.} \mathrm{The} \mathrm{study}$ indicated that fermented fish silage prepared from viscera and gills of Indian major caps remained shelf worthy for a period of 60 days and the use of jaggery at concentrations higher than $20 \%(\mathrm{w} / \mathrm{w})$ would not be viable as it led to faster spoilage rate and increased cost of production.
\end{abstract}

Keywords: Fermented silage, Indian major carps, Jaggery, pH, Total volatile base nitrogen

\section{Introduction}

Aquaculture in India is dominated by carps which contribute to more than $80 \%$ of the total production. Large quantities of waste is generated during processing of carps which has great potential to be used as protein supplements in aquaculture, poultry and livestock feed. It has been estimated that visceral waste of fish alone contributes to around 3,00,000 t (Mahendraker, 2000). Fish silage is reported to have high nutritional value with all the essential amino acids (Vidotti et al., 2003), which can be used as a high value protein source for feeding different animals such as broilers (Al-Marzooqi et al., 2010), pigs (Kjos et al., 1999), laying hens (Kjos et al., 2001), sheep (Rahmi et al., 2008), fish (Borghesi et al., 2008) and laying quails (Zynudheen et al., 2008). Several studies have been reported on production of fermented fish silage from marine fish offals using jaggery and Lactobacillus planatrum inocula (Babu et al., 2005; Zynudheen et al., 2008; Samaddar and Kaviraj, 2014). The shift in focus to freshwater carp culture in recent years due to the stagnancy in marine fish production led to develop strategies for the utilisation of freshwater carp processing wastes like gut and viscera. The present work was designed to evaluate the biochemical and microbiological quality of fermented silage prepared from the dressing waste of carps (gut and gills) and to study the effect of varying levels of carbohydrates on the quality changes.

\section{Materials and methods}

Preparation of fermented fish waste silage

Fresh viscera and gills, from dressing wastes of Indian major carps (IMCs), were collected from the local market and transported to the laboratory in ice. The raw material was washed in potable water, minced and $30 \%(\mathrm{v} / \mathrm{w})$ water was added to the mince. Two batches of fermented silages were prepared by adding, jaggery as carbohydrate source at the rate of $10 \% \mathrm{w} / \mathrm{w}(\mathrm{F} 1)$ and $20 \% \mathrm{w} / \mathrm{w}(\mathrm{F} 2)$ respectively. Freeze dried culture of Lactobacillus plantarum procured from Microbial Type Culture Collection and Gene Bank (MTCC), Chandigarh was revived in Lactobacillus MRS medium by incubating at $37^{\circ} \mathrm{C}$ for $48 \mathrm{~h}$. The fish mince-jiggery mixture was cooked for $30 \mathrm{~min}$, cooled down to room temperature and then $5 \mathrm{ml}$ of inoculum of L. planatrum $\left(10^{5}\right.$ cells $\left.\mathrm{ml}^{-1}\right)$ was added to both the batches. Ensilation was done in airtight plastic containers at ambient temperature $\left(28 \pm 2^{\circ} \mathrm{C}\right)$. The silages were stirred twice daily and samples were drawn periodically at $0,2,7,15,30$ and 60 days to assess the biochemical and microbiological quality.

Biochemical analysis

$\mathrm{pH}$ of the silage in distilled water $(1: 5 \mathrm{~W} / \mathrm{V})$ was determined using a glass electrode digital $\mathrm{pH}$ meter (Cyberscan 510, Eutech Instruments, Singapore). Proximate 
composition of the raw material and silage were analysed following AOAC (2000) procedures. Total volatile base nitrogen (TVB-N) was estimated by the microdiffusion method (Conway, 1950). Oxidation stability of the sample was assessed by measuring Thiobarbituric acid (TBA) value (Tarladgis et al., 1960).

\section{Microbiological analysis}

Microbiological quality of raw material and fermented silage was assessed by enumerating the total plate count (TPC) and yeast and mould count following BAM (1995) and total lactic acid bacteria (LAB) count using de Man Regossa Sharpe (MRS) agar. For enumeration of TPC, plate count agar (PCA) was used and the plates were incubated for $48 \mathrm{~h}$ at $37^{\circ} \mathrm{C}$. For enumeration of LAB, MRS agar plates were incubated at $37^{\circ} \mathrm{C}$ in a carbon dioxide incubator for 48-72 h. Yeast and mold were isolated using Rose Bengal Chloramphenicol (RBC) agar after incubating the plates for 3 to 5 days at room temperature.

\section{Statistical analysis}

The complete data set consisted of matrix of order $36 \times 8$, where the rows represented the treatments (2), days (6) with 3 replications and the columns represented the biochemical and microbiological quality parameters (6). All variables were checked for normality (Shapiro - Wilk test) and homogeneity of variances (Levene test). One way analysis of variance (ANOVA) or nonparametric ANOVA (KruskalWallis test) was performed to obtain significant differences between treatments and Tukey's HSD test (Honestly Significant Difference) or Nemenyi test (nonparametric) was used to compare the treatment means. Pearson's (normal data) and Spearman's (non-normal data) correlation coefficients were computed to understand the linear relationship among different quality parameters. SAS 9.3 software was used for all statistical computations.

\section{Results and discussion}

Proximate composition of raw material and fermented fish waste silage

The raw material had $75.86 \%( \pm 2.63)$ moisture, $9.11 \%$ $( \pm 0.94)$ protein, $9.8 \%( \pm 1.12)$ crude fat and $1.03 \%( \pm 0.19)$ ash. Low crude protein observed in the fermented fish silages may be due to the addition of jaggery and L. plantarum inoculum and also due to the slight dilution effect by the acid produced (Table 1). Silage prepared with higher jaggery concentration (F2) was found to have lower crude fat and ash content. Dry matter in F2 was significantly higher $(\mathrm{p}<0.05)$ than that of F1, possibly because of the higher content of jaggery. Significantly, higher lipid content in fermented silage than in the raw material could be accounted for by the fact that lactic acid is soluble in ether and hence extractable during lipid extraction (Stetcher et al., 1968).
Table 1. Proximate composition of fermented fish silage prepared from dressing wastes of carps by adding different levels of jaggery

\begin{tabular}{llll}
\hline Proximate composition & Fish waste & F1 & F2 \\
\hline Moisture (\%) & $75.86 \pm 2.63^{\mathrm{a}}$ & $75.77 \pm 0.03^{\mathrm{a}}$ & $68.56 \pm 0.03^{\mathrm{b}}$ \\
Crude protein (\%) & $9.11 \pm 0.94^{\mathrm{a}}$ & $4.67 \pm 0.17^{\mathrm{b}}$ & $5.07 \pm 0.08^{\mathrm{b}}$ \\
Crude fat (\%) & $9.8 \pm 1.12^{\mathrm{a}}$ & $13.04 \pm 0.61^{\mathrm{b}}$ & $12.81 \pm 0.11^{\mathrm{b}}$ \\
Ash (\%) & $1.03 \pm 0.19^{\mathrm{a}}$ & $1.54 \pm 0.05^{\mathrm{b}}$ & $1.41 \pm 0.11^{\mathrm{b}}$ \\
\hline
\end{tabular}

$\mathrm{F} 1=$ fermented fish silage prepared by addition of $10 \%$ jaggery

F2 $=$ fermented fish silage prepared by addition of $20 \%$ jaggery

Means bearing different superscripts in the same row differ significantly $(\mathrm{p}<0.05)$

\section{Biochemical changes in fermented fish waste silage}

$p H$

Maintenance of acidic $\mathrm{pH}$ in fish silage is important for keeping the product more hygienic and safe, by inhibiting the growth of pathogenic organisms. $\mathrm{pH}$ values ranging from 4-5 are recommended for biological silages (Ahmed and Mahendrakar, 1996; Faid et al., 1997). Silage at $\mathrm{pH}$ value of 4.5 and above is always susceptible to spoilage caused by Clostridium botulinum, Staphylococcus aureus and fungi (FAO, 1971). In fermented silages with $10 \%$ (F1) and 20\% (F2) jaggery, $\mathrm{pH}$ value dropped to $<4.5$ by the $2^{\text {nd }}$ day (Fig. 1). This indicates successful fermentation with lactic acid production by the L. plantarum inoculum added. Several species of the genus Lactobacillus have temperature optima ranging from 30 to $40^{\circ} \mathrm{C}$ (Kandler and Weiss, 1984). Hence, the storage temperature maintained at $28-30^{\circ} \mathrm{C}$ would have helped in the proliferation of bacteria. In the batch added with $20 \%$ jaggery (F2), pH stabilised around 4.02 at the end of 15 days, where as in the lot with $10 \%$ jaggery (F1), $\mathrm{pH}$ got stabilised at a little higher value of 4.11 at the end of

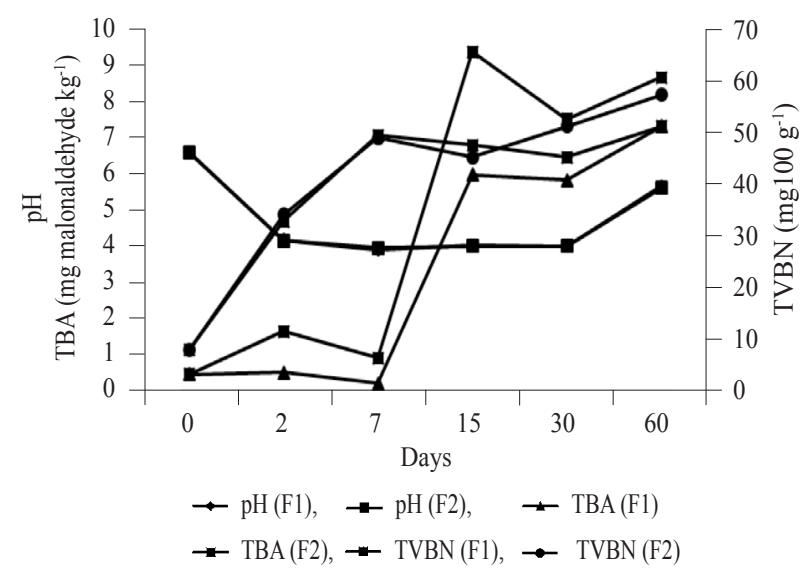

Fig. 1. Variation in $\mathrm{pH}, \mathrm{TVBN}$ and TBA of fermented silage prepared from dressing waste of Indian major carps using different concentrations of jaggery

$\mathrm{F} 1=$ fermented fish silage prepared by addition of $10 \%$ jaggery

F2 $=$ fermented fish silage prepared by addition of $20 \%$ jaggery

TVBN - Total volatile base nitrogen $\left(\mathrm{mg} 100 \mathrm{~g}^{-1}\right)$

TBA - thiobarbituric acid (mg malonaldehyde $\mathrm{kg}^{-1}$ ) 
15 days (Fig.1). F2 showed a significantly $(\mathrm{p}<0.05)$ lower $\mathrm{pH}$ value from the $7^{\text {th }}$ to $30^{\text {th }}$ day of storage. Babu et al. (2005) reported a decrease in $\mathrm{pH}$ with increase in concentration of carbohydrate source. The increase in $\mathrm{pH}$ value, in both the treatments after $30^{\text {th }}$ day of storage indicates spoilage of the samples (Fig. 1). During storage, autolysis affects the buffering capacity of the material and increases $\mathrm{pH}$, which lowers the storage potential.

\section{Total volatile base nitrogen (TVB-N)}

Volatile amines are the characteristic molecules responsible for the fishy odour and flavour present in fish several days after the catch. TVB-N value is a traditional chemical means most widely used for evaluation of the degree of spoilage in seafood. It consists mainly of a mixture of ammonia, dimethyl amine (DMA) and trimethylamine (TMA) and other nitrogen compounds which become volatile in alkaline condition. The raw material had a TVB-N content of 7.93( \pm 1.61$) \mathrm{mg} \%$. By ensilation, the TVB-N values of both F1 and F2 increased significantly $(\mathrm{p}<0.05)$ by the $2^{\text {nd }}$ day (Fig. 2). Faid et al. (1997) reported an increasing pattern of $T V B=N$ with fermentation. Significant difference $(p<0.05)$ in TVB-N concentration between F1 and F2 was noticed from the $30^{\text {th }}$ day of storage (Fig.1). Babu et al. (2005) observed that the level of volatile amino acids in fermented fish silages increase with the amount of carbohydrate used. The TVB-N values in both F1 and F2 reached maximum of 51.8 and $57.86 \mathrm{mg} \%$ respectively by the end of 60 days of storage. Zynudheen et al. (2008) observed an increase in TVB-N from 10 to $64 \mathrm{mg} \%$ within 15 days of storage in fermented silage prepared from Nile tilapia. Higher concentrations of TVB-N has been reported from silverbelly silage $(116 \mathrm{mg} \%$ ) (Babu et al., 2005) and pelagic sardine silage (63 mg\%) (Siddique,

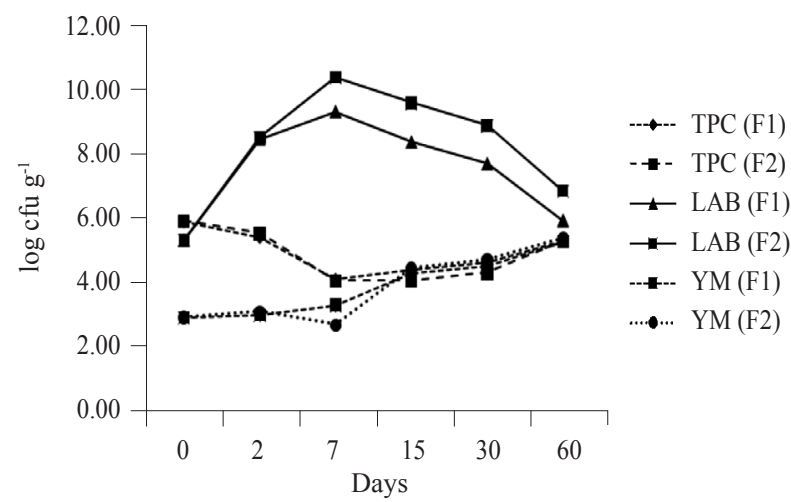

Fig. 2. Variations in TPC, LAB and YM of fermented silage prepared from dressing waste of Indian major carps using different concentrations of jaggery

$\mathrm{F} 1=$ fermented fish silage prepared by addition of $10 \%$ jaggery F2 $=$ fermented fish silage prepared by addition of $20 \%$ jaggery

TPC - Total plate count (log $\left.\mathrm{cfu} \mathrm{g}^{-1}\right)$

LAB - Lactic acid bacteria $\left(\log\right.$ cfu $\left.\mathrm{g}^{-1}\right)$

YM - Yeast and moulds (log cfu $\left.\mathrm{g}^{-1}\right)$
2009), respectively. Spoilage by total volatile bases is comparatively less in freshwater fish waste silage, possibly because of the absence of Trimethylamine oxide (TMAO) or the presence of very little concentration of it in those fishes.

\section{Thiobarbituric acid (TBA) values}

Auto-oxidation is the most common process leading to oxidative deterioration and is defined as the spontaneous reaction of atmospheric oxygen with lipids. TBA is a good indicator of the quality of fish. It is widely used as indicator for the assessment of degree of lipid oxidation. Fresh dressing waste of carps had a TBA value of $0.47 \pm 0.01 \mathrm{mg}$ malonaldehyde $\mathrm{kg}^{-1}$. TBA value in both F1 and F2 showed fluctuations all through the storage period. The high fat content in the carp viscera is the possible reason for the increasing rate of auto-oxidation in fermented silage. Throughout the storage study, the TBA value recorded in F2 was significantly higher than that of F1 (Fig.1). At the end of 60 days of storage, the TBA value reached $7.39 \mathrm{mg}$ malonaldehyde $\mathrm{kg}^{-1}$ and $8.76 \mathrm{mg}$ malonaldehyde $\mathrm{kg}^{-1}$ in $\mathrm{F} 1$ and F2 respectively. Fagbenro et al. (1994) observed that the fermented silage prepared from raw tilapia had a TBA content of $13 \mathrm{mg}$ malonaldehyde $\mathrm{kg}^{-1}$ within one month of storage. The drastic increase in TBA value indicates the possible role of carbohydrate in augmenting lipid auto-oxidation in fermented silage.

\section{Microbiological changes}

Fresh dressing waste had a bacterial load of around $5 \log$ cfu g $\mathrm{g}^{-1}$. The utilisation of fermented fish silage in livestock, poultry and aqua feed depends upon the rapid growth and acid production by lactic acid bacteria (LAB) thereby eliminating pathogens and arresting the growth of other spoilage microbes. The total plate count of bacteria was not affected significantly by the reduction in $\mathrm{pH}$ by the $2^{\text {nd }}$ day (Fig. 2). This could be attributed to the growth of L. plantarum in the silage. The strong negative correlation between $\mathrm{pH}$ value and LAB growth (correlation coefficient - 0.8405) shows that low $\mathrm{pH}$ favours the growth of LAB. Thereafter, total bacterial load reduced significantly till the $7^{\text {th }}$ day of storage. Significant increase $(\mathrm{p}<0.05)$ in TPC from $30^{\text {th }}$ day correlates well with the increase in $\mathrm{pH}$ (correlation coefficient - 0.93). Maximum LAB concentration was recorded on $7^{\text {th }}$ day of storage (Fig. 2). After stabilisation of $\mathrm{pH}$, the maximum LAB counts were around $9 \log \mathrm{cfu} \mathrm{g}^{-1}$ in $\mathrm{F} 1$ and $10 \log \mathrm{cfu} \mathrm{g}^{-1}$ in F2. After the growth phase, decrease in LAB counts was observed from the $7^{\text {th }}$ day. This decrease in $\mathrm{LAB}$ counts during the second week of incubation could be attributed to the autolysis of the lactic acid bacteria after the stationary growth phase (Zahar et al., 2002). A 2 log cycle reduction observed in $\mathrm{LAB}$ values from $30^{\text {th }}$ day could be due to the competition from the growth of other spoilage bacteria. The yeast and mould (YM) count began to increase 
significantly from the $15^{\text {th }}$ day of storage. Yeast and mould count continuously increased till the $60^{\text {th }}$ day of storage (Fig. 2). Growth of YM as well as LAB was without antagonism, which indicated suitable conditions for growth during fermentation. The decrease in $\mathrm{pH}$ value also proved to be encouraging for the growth of yeasts in the medium. Faid et al. (1997) demonstrated that fermentation of fish silage by LAB can be improved by addition of yeasts for combined alcohol or lactate fermentation.

The present study suggests that fermented silage prepared from dressing wastes (gut and gills) of Indian major carps can be a potential source of animal protein and lipid in feed stuffs. The silage was found to have a shelf life of 60 days at room temperature regardless of the amount of carbohydrate used. But the addition of jaggery at $10 \% \mathrm{w} / \mathrm{w}$ was found to be adequate for successful fermentation of the fish waste. A higher concentration $(20 \% \mathrm{w} / \mathrm{w})$ of the carbohydrate source was found to augment the rate of spoilage and will invariably lead to increase in cost of production of the silage.

\section{Acknowledgements}

The authors are grateful to the Director, ICAR-Central Institute for Women in Agriculture (ICAR-CIWA), Bhubaneswar for granting permission to carry out the work and for providing the necessary facilities.

\section{References}

Ahmed, J. and Mahendrakar, N. S. 1996. Growth and meat quality of broiler chicks fed with fermented fish viscera silage. Intl. J. Anim. Sci., 11: 1-5.

Al-Marzooqi, W., Al-Farsi, M. A., Kadim, I. T., Mahgoub, O. and Goddard, J. S. 2010. The effect of feeding different levels of sardine fish silage on broiler performance, meat quality and sensory characteristics under closed and open-sided housing systems. Asian Aust. J. Anim. Sci., 23: 1614-1625.

AOAC 2000. Official methods of analysis, $17^{\text {th }}$ edn., Association of Official Analytical Chemists, Washington DC, USA.

Babu, U. S. J., Rao, B. M., Khasim, D. I. and Nair, K. G. R. 2005. Biochemical and microbiological quality of formic acid silage and Lactobacillus fermented silage. Fish. Technol., 42(2): $163-170$

BAM 1995. Bacteriological analytical manual, $8^{\text {th }}$ edn. AOAC International, Gaithersburg, USA. 614 pp.

Borghesi, R., Portz, L., Oetterer, M. and Zyrino, J. E. P. 2008. Apparent digestibility coefficient of protein and aminoacids of acid, biological and enzymatic silage for Nile tilapia (Oreochromis niloticus). Aquac. Nutr., 14: 242-248.

Conway, E. J. 1950. Microdiffusion analysis and volumetric error, $3^{\text {rd }}$ edn. Lockwood and Son Ltd., Crosby, London.

Fagbenro, O., Jauncey, K. and Haylor, G. 1994. Nutritive value of diets containing dried lactic acid fermented fish silage and soybean meal for juvenile Oreochromis niloticus and Clarias gariepinus. Aquat. Living Resour., 7: 79-85.

Faid, M., Zouiten, A., Elmarrakchi, A. and Achkari-Begdouri, A. 1997. Biotransformation of fish waste into a stable feed ingredient. Food Chem., 60: 13-18.

FAO 1971. Fermented fish products, Fisheries Report 100, FAO, Rome, Italy. 54 pp.

Kandler, O. and Weiss, N. 1984. Genus Lactobacillus Beijerinck 1901, 212. In: Holt, J. G. (Ed.), Bergey's manual of systematic bacteriology vol. 1. Williams and Wilkins, Baltimore, USA. p. 1209-1234.

Kjos, N. P., Skrede, A. and Overland, M. 1999. Effects of dietary fish silage and fish fat on growth performance and sensory quality of growing-finishing pigs. Can. J. Anim. Sci., 79: 139-147.

Kjos, N. P., Herstad, O., Skrede, A. and Overland, M. 2001. Effects of dietary fish silage and fish fat on performance and egg quality of laying hens. Can. J. Anim. Sci., 81: 245 - 251.

Mahendrakar, N. S. 2000. Aquafeeds and meat quality of cultured fish. In: John, G. and Ninawe, A. S. (Eds.), Aquaculture-feed and health. Biotech. Consort. India Ltd., New Delhi. p. 26-30.

Rahmi, M., Faid, M., El Yachioui, M., Berny, E. H., Fakir, M. and Ouhssine, M. 2008. Protein rich ingredients from fish waste for sheep feeding. Afr. J. Microbiol. Res., 2: 73-77.

Samaddar, A. and Kaviraj, A. 2014. Processing of fish offal waste through fermentation utilising whey as inoculum. Int. J. Recycl. Org. Waste Agric., 3: 45-49.

Siddique Milad El-Ajnaf 2009. Development of fermented fish silage derived from pelagic sardine and apple pomace by-product for inclusion in diets for the European seabass (Dicentrarchus labrax). Ph. D. Thesis. University of Plymouth. United Kingdom.

Stecher, G. B., Windholz, M., Leahy, S., Bolton, D. and Eaton, L. 1968. Merck Index, $8^{\text {th }}$ edn. Merck and Co., Inc. Raltamy, New Jersey, USA.

Tarladgis, B. G., Watts, B. M., Younthan, M. T. and Dugan, L. R. 1960. A distillation method for the quantitative determination of malonaldehyde in rancid oil. J. Am. Oil Chem. Soc., 37: 403-406.

Vidotti, R. M., Viegas, E. M. M. and Carneiro, D. J. 2003. Aminoacid composition of processed fish silage using different raw materials. Anim. Feed Sci. Technol., 105: 199-204.

Zahar, M., Menkerrouml, N., Guerouali, A., Baoul, S. and Alahiane, I. 2002. Biological ensiling of sardine wastes in sugarcane molasses for their valorisation in animal feeding: Microbiological study. Proceedings of International Symposium on Environmental pollution control and waste management, $7^{\text {th }}-10^{\text {th }}$ January, 2002, Tunis, p. 304-311. 
Zynudheen, A. A., Anandan, R. and Ramachandran, G. 2008 Effect of dietary supplementation of fermented fish silage on egg production in Japanese quail (Coturnix coromandelica). Afr. J. Agr. Res., 3: 379-383.
Zynudheen, A. A., Nirmala, T., Jose, J. and Ramachandran Nair, K. G. 2008. Effect of different levels of fermentable carbohydrate on the degree of hydrolysis of fish silage. Fish. Technol., 45: 43-48.

Date of Receipt : : 03.10.2015

Date of Acceptance : 01.07.2016 